\title{
Benign Neck Neoplasm
}

National Cancer Institute

\section{Source}

National Cancer Institute. Benign Neck Neoplasm. NCI Thesaurus. Code C4884.

A non-metastasizing neoplasm that arises from the neck region. 